\title{
Diet formulation techniques and lysine requirements of 1- to 22-day-old broilers

\section{-Author(s)}

Siqueira $\mathrm{JC}^{1,2}$

Sakomura NK²

Dourado LRB $^{3}$

Ezequiel $\mathrm{JMB}^{2}$

Barbosa NAA ${ }^{4}$

Fernandes $\mathrm{JBK}^{5}$

Centro de Ciências Agrárias e Ambientais, Universidade Federal do Maranhão, BR 222, km 04, CEP 65500-000, Chapadinha, MA

2 Departamento de Zootecnia, Faculdade de Ciências Agrárias e Veterinárias, Universidade Estadual Paulista, Via de Acesso Prof. Paulo Donato Castellane, s/n, CEP 14884-900, Jaboticabal, SP

Departamento de Zootecnia, Universidade Federal do Piauí, BR 135, km 03, CEP 64900-000, Bom Jesus, PI

4 BOAV Alimentos LTDA, Estrada Vicinal Casa Branca/Tambaú, km 8,5, CEP 13700-000, Casa Branca, SP

5 Centro de Aquicultura da Universidade Estadual Paulista, Via de Acesso Prof. Paulo Donato Castellane, s/n, CEP 14884-900, Jaboticabal, SP

\section{-Mail Adress}

*Corresponding author e-mail address

E-mail: jcsiqueira@ufma.br

\section{nKeywords}

Broilers, diet formulation, dose-response, lysine, performance.

Part of this article was published in the proceedings of Reunião Anual da Sociedade Brasileira de Zootecnia, 2009.

\section{ABSTRACT}

Two experiments were carried out to compare two techniques (amino acid supplementation and dilution) for formulating experimental diets for pre-starter (1 to 8 days) and starter (8 to 22 days) broiler chicks and to estimate digestible lysine requirements using the doseresponse method. In each experiment, 1,200 male Cobb 500 chickens were randomly distributed according to a $5 \times 2$ factorial arrangement (lysine level $x$ formulation technique) with six replicates of 20 birds each. For the supplemented diet, a basal diet was formulated to meet the nutritional requirements, then L-lysine $\mathrm{HCl}$ was added to achieve digestible lysine levels of $0.975,1.082,1.189,1.296$ and $1.403 \%$ in the pre-starter diets and $0.840,0.932,1.024,1.116$ and $1.208 \%$ in the starter diets. For the diluted diet, a diet high in crude protein (CP) and relatively low in lysine was formulated and to which was added a protein-free diet until lysine levels were similar to those described above for the supplemented diet. The results suggest that the dilution technique favored the performance potential and better met lysine requirements compared with the supplementation technique. Lysine levels required for optimal feed conversion ratio of broilers during the pre-starter and starter phases were estimated at 1.361 and $1.187 \%$, which are equivalent to lysine intake of 0.340 and $0.797 \mathrm{~g} /$ day, respectively.

\section{INTRODUCTION}

Lysine is an essential amino acid closely associated with body protein deposition potential. It is considered the second limiting amino acid for broilers fed diets based on corn and soybean meal. For these reasons lysine was chosen as the reference amino acid for the "ideal protein" concept, which bases dietary amino acid concentrations on fixed ratios to lysine (Baker \& Han, 1994). In such diets, changing the lysine concentration will change the requirements for all other essential amino acids. This explains the importance of obtaining accurate and precise estimates of broiler lysine requirements.

Broiler responses to dietary lysine levels have been studied for decades. Several articles have been published on this subject, but their results are contradictory because numerous factors, including experimental methodology, influence lysine requirement determination.

The dose-response method has been traditionally applied to estimate broiler lysine requirements (Sakomura \& Rostagno, 2007). The technique used to formulate the experimental diets is an important aspect of this method. Most studies apply the amino acid supplementation (D'Mello, 1982), but this method has been criticized (Fisher \& Morris, 1970; Gous, 


\section{Diet formulation techniques and lysine requirements of 1- to 22-day-old broilers}

1980; Moughan \& Fuller, 2003), particularly because successively increasing the levels of the limiting amino acid may change its balance relative to the other amino acids, which may affect broiler responses.

Another formulation technique, proposed by Fisher \& Morris (1970), consists in sequentially diluting a high-protein diet, which is relatively deficient in the tested amino acid, with an isoenergetic, protein-free diet. This dilution results in diets with intermediate levels of the tested amino acid. According to Gous
(1980), this technique produces more reliable results than the amino acid supplementation technique, as it provides constant amino acid ratios across the evaluated treatments.

Because the concentration and ratio of essential and nonessential amino acids may directly affect broiler ability to efficiently use dietary amino acids (Heger \& Frydrych, 1989), and because supplementation and dilution produce diets with different amino acid ratios, broiler responses may be influenced by the technique used to formulate experimental diets.

Table 1 - Diets formulated by the supplementation technique for 1 - to 8-day-old broilers ${ }^{\dagger}$

\begin{tabular}{|c|c|c|c|c|c|c|c|c|c|c|}
\hline \multirow[t]{2}{*}{ Ingredients (\%) } & \multicolumn{10}{|c|}{ Digestible lysine level (\%) } \\
\hline & \multicolumn{2}{|c|}{0.975} & \multicolumn{2}{|c|}{1.082} & \multicolumn{2}{|c|}{1.189} & \multicolumn{2}{|c|}{1.296} & \multicolumn{2}{|c|}{1.403} \\
\hline Corn & \multicolumn{2}{|c|}{57.664} & \multicolumn{2}{|c|}{57.664} & \multicolumn{2}{|c|}{57.664} & \multicolumn{2}{|c|}{57.664} & \multicolumn{2}{|c|}{57.664} \\
\hline Soybean meal & \multicolumn{2}{|c|}{33.850} & \multicolumn{2}{|c|}{33.850} & \multicolumn{2}{|c|}{33.850} & \multicolumn{2}{|c|}{33.850} & \multicolumn{2}{|c|}{33.850} \\
\hline Dicalcium phosphate & \multicolumn{2}{|c|}{1.962} & \multicolumn{2}{|c|}{1.962} & \multicolumn{2}{|c|}{1.962} & \multicolumn{2}{|c|}{1.962} & \multicolumn{2}{|c|}{1.962} \\
\hline Limestone & \multicolumn{2}{|c|}{0.937} & \multicolumn{2}{|c|}{0.937} & \multicolumn{2}{|c|}{0.937} & \multicolumn{2}{|c|}{0.937} & \multicolumn{2}{|c|}{0.937} \\
\hline Soybean oil & & & & & & & & & & 610 \\
\hline Sodium chloride & & & & & & & & & & 516 \\
\hline Mineral supplement ${ }^{\ddagger}$ & & & & & & & & & & 050 \\
\hline Vitamin supplement ${ }^{\S}$ & & & & & & & & & & 025 \\
\hline Choline chloride (70\%) & & & & & & & & & & 070 \\
\hline Anticoccidial $^{*}$ & & & & & & & & & & 050 \\
\hline L-lysine $\mathrm{HCl}(78.5 \%)$ & & & & & & & & & & 543 \\
\hline DL-methionine (99\%) & & & & & & & & & & 487 \\
\hline L-threonine (99\%) & & & & & & & & & & 280 \\
\hline L-valine (99\%) & & & & & & & & & & 248 \\
\hline L-isoleucine (99\%) & & & & & & & & & & 161 \\
\hline L-tryptophan (99\%) & & & & & & & & & & 045 \\
\hline L-arginine $(99 \%)$ & & & & & & & & & & 235 \\
\hline L-glutamic acid (99\%) & & & & & & & & & & 082 \\
\hline Corn starch & & & & & & & & & & 186 \\
\hline Total & & & & & & & & & & 0.00 \\
\hline Digestible amino acids (\%) & & aa/Lys & & aa/Lys & & aa/Lys & & aa/Lys & & aa/Lys \\
\hline Lysine $(100)^{ \pm}$ & 0.975 & 100 & 1.082 & 100 & 1.189 & 100 & 1.296 & 100 & 1.403 & 100 \\
\hline Methionine+cystine(71) & 0.728 & 74 & 0.807 & 74 & 0.886 & 74 & 0.965 & 74 & 1.043 & 74 \\
\hline Methionine (39) & 0.451 & 46 & 0.530 & 49 & 0.609 & 51 & 0.688 & 53 & 0.766 & 55 \\
\hline Threonine (65) & 0.687 & 70 & 0.742 & 68 & 0.814 & 68 & 0.886 & 68 & 0.959 & 68 \\
\hline Valine (75) & 0.855 & 88 & 0.855 & 79 & 0.934 & 79 & 1.017 & 78 & 1.100 & 78 \\
\hline Isoleucine (65) & 0.799 & 82 & 0.799 & 74 & 0.814 & 68 & 0.886 & 68 & 0.959 & 68 \\
\hline Tryptophan (16) & 0.224 & 23 & 0.224 & 21 & 0.227 & 19 & 0.248 & 19 & 0.268 & 19 \\
\hline Arginine (105) & 1.291 & 132 & 1.291 & 119 & 1.294 & 109 & 1.409 & 109 & 1.523 & 109 \\
\hline Leucine (108) & 1.649 & 169 & 1.649 & 152 & 1.649 & 139 & 1.649 & 127 & 1.649 & 117 \\
\hline Phenylalanine (63) & 0.934 & 96 & 0.934 & 86 & 0.934 & 79 & 0.934 & 72 & 0.934 & 67 \\
\hline Glycine+serine $(150)^{\#}$ & 1.906 & 179 & 1.906 & 162 & 1.906 & 149 & 1.906 & 138 & 1.906 & 128 \\
\hline
\end{tabular}

${ }^{+}$Calculated composition: metabolizable energy, 2,960 kcal/kg; crude protein, 22.73\%; available P, 0.470\%; Ca, 0.939\%; Na, 0.223\%.

‡Content per kg: Mn, 150 g; Fe, 100 g; Zn, 100 g; Cu, 16 g; I, 1.5 g.

${ }^{\S}$ Content per kg: folic acid, $1 \mathrm{~g}$; pantothenic acid, $15 \mathrm{~g}$; niacin, $40 \mathrm{~g}$; biotin, $60 \mathrm{mg}$; vitamin $\mathrm{B}_{1^{\prime}} 1.8 \mathrm{~g}$; vitamin $\mathrm{B}_{12}, 12 \mathrm{~g}$; vitamin $\mathrm{B}_{2^{\prime}} 6 \mathrm{~g}$; vitamin $\mathrm{B}_{6^{\prime}}, 2.8 \mathrm{~g}$; vitamin $\mathrm{D}_{3^{\prime}} 2.000 .000 \mathrm{Ul}$; vitamin E, 15 g; vitamin $\mathrm{K}_{3}$ 1.8 g; Se, 300 mg; butylatedhydroxytoluene, $500 \mathrm{mg}$

"Sodiumsalinomycin $(60 \mathrm{mg} / \mathrm{kg})$.

fldeal protein ratios (aa/Lys) recommended by Rostagno et al. (2005).

\#Values and ratios defined on total amino acid basis. 
Therefore, this study aimed at comparing the effects of amino acid supplementation and diet dilution techniques and to estimate the digestible lysine requirements for pre-starter ( 1 to 8 day old) and starter ( 8 to 22 day old) broiler chickens using a dose-response method.

\section{MATERIALS AND METHODS}

Two experiments were conducted at the poultry sector of the Department of Animal Science of the School of Agrarian Sciences and Veterinary Medicine,
São Paulo State University, state of São Paulo, Brazil. The study was approved by the Ethics and Animal Welfare Commission of that institution.

\section{Birds, facilities, and management}

In each of the two experiments, 1,200 male Cobb 500 broiler chickens, with initial body weight $( \pm$ standard deviation) of $39.31 \pm 0.02 \mathrm{~g}$ and $139.03 \pm$ 0.07 gat the beginning of the pre-starter phase ( 1 to 8 days) and the starter phase (8 to 22 days), respectively, totaling 2,400 birds.

Table 2 - Diets formulated by the supplementation method fed to8- to 22-day-old broilers ${ }^{\dagger}$

\begin{tabular}{|c|c|c|c|c|c|c|c|c|c|c|}
\hline \multirow{2}{*}{ Ingredients (\%) } & \multicolumn{10}{|c|}{ Digestible lysine level (\%) } \\
\hline & \multicolumn{2}{|c|}{0.840} & \multicolumn{2}{|c|}{0.932} & \multicolumn{2}{|c|}{1.024} & \multicolumn{2}{|c|}{1.116} & \multicolumn{2}{|c|}{1.208} \\
\hline Corn & \multicolumn{2}{|c|}{64.281} & \multicolumn{2}{|c|}{64.281} & \multicolumn{2}{|c|}{64.281} & \multicolumn{2}{|c|}{64.281} & \multicolumn{2}{|c|}{64.281} \\
\hline Soybean meal & \multicolumn{2}{|c|}{27.971} & \multicolumn{2}{|c|}{27.971} & \multicolumn{2}{|c|}{27.971} & \multicolumn{2}{|c|}{27.971} & \multicolumn{2}{|c|}{27.971} \\
\hline Dicalcium phosphate & \multicolumn{2}{|c|}{1.840} & \multicolumn{2}{|c|}{1.840} & \multicolumn{2}{|c|}{1.840} & \multicolumn{2}{|c|}{1.840} & \multicolumn{2}{|c|}{1.840} \\
\hline Limestone & \multicolumn{2}{|c|}{0.903} & \multicolumn{2}{|c|}{0.903} & \multicolumn{2}{|c|}{0.903} & \multicolumn{2}{|c|}{0.903} & \multicolumn{2}{|c|}{0.903} \\
\hline Soybean oil & & & & & & & & & & \\
\hline Sodium chloride & & & & & & & & & & \\
\hline Mineral supplement ${ }^{\ddagger}$ & & & & & & & & & & \\
\hline Vitamin supplement § & & & & & & & & & & \\
\hline Choline chloride (70\%) & & & & & & & & & & \\
\hline Anticoccidial ${ }^{¥}$ & & & & & & & & & & \\
\hline L-lysine $\mathrm{HCl}(78.5 \%)$ & & & & & & & & & & \\
\hline DL-methionine (99\%) & & & & & & & & & & \\
\hline L-threonine (99\%) & & & & & & & & & & \\
\hline L-valine $(99 \%)$ & & & & & & & & & & \\
\hline L-isoleucine (99\%) & & & & & & & & & & \\
\hline L-tryptophan (99\%) & & & & & & & & & & \\
\hline L-arginine (99\%) & & & & & & & & & & \\
\hline L-glutamic acid (99\%) & & & & & & & & & & \\
\hline Corn starch & & & & & & & & & & \\
\hline Total & & & & & & & & & & \\
\hline Digestible amino acids (\%) & & aa/Lys & & aa/Lys & & aa/Lys & & aa/Lys & & aa/Lys \\
\hline Lysine $(100)^{f}$ & 0.840 & 100 & 0.932 & 100 & 1.024 & 100 & 1.116 & 100 & 1.208 & 100 \\
\hline Methionine+cystine(71) & 0.628 & 74 & 0.695 & 74 & 0.764 & 74 & 0.831 & 74 & 0.899 & 74 \\
\hline Methionine (39) & 0.371 & 44 & 0.438 & 47 & 0.506 & 49 & 0.574 & 51 & 0.642 & 53 \\
\hline Threonine (65) & 0.613 & 73 & 0.639 & 68 & 0.701 & 68 & 0.764 & 68 & 0.826 & 68 \\
\hline Valine (75) & 0.765 & 91 & 0.765 & 82 & 0.804 & 78 & 0.877 & 78 & 0.948 & 78 \\
\hline Isoleucine (65) & 0.704 & 84 & 0.704 & 76 & 0.704 & 69 & 0.764 & 68 & 0.826 & 68 \\
\hline Tryptophan (16) & 0.195 & 23 & 0.195 & 21 & 0.195 & 19 & 0.213 & 19 & 0.231 & 19 \\
\hline Arginine (105) & 1.126 & 134 & 1.127 & 121 & 1.127 & 110 & 1.214 & 108 & 1.313 & 108 \\
\hline Leucine (108) & 1.524 & 181 & 1.524 & 163 & 1.524 & 149 & 1.524 & 137 & 1.524 & 126 \\
\hline Phenylalanine (63) & 0.834 & 99 & 0.834 & 89 & 0.834 & 81 & 0.834 & 75 & 0.834 & 69 \\
\hline Glycine+serine (150)\# & 1.704 & 185 & 1.704 & 168 & 1.704 & 154 & 1.704 & 143 & 1.704 & 132 \\
\hline
\end{tabular}

${ }^{+}$Calculated composition: metabolizable energy, 3,000 kcal/kg; crude protein, 20.47\%; available P, 0.442\%; Ca, 0.884\%; Na, 0.214\%.

${ }^{\ddagger}$ Content per kg: Mn, $150 \mathrm{~g} ; \mathrm{Fe}, 100 \mathrm{~g} ; \mathrm{Zn}, 100 \mathrm{~g} ; \mathrm{Cu}, 16 \mathrm{~g} ; \mathrm{l}, 1.5 \mathrm{~g}$.

§ Content per kg: folic acid, $1 \mathrm{~g}$; pantothenic acid, $15 \mathrm{~g}$; niacin, $40 \mathrm{~g}$; biotin, 60 mg; vitamin $\mathrm{B}_{1}, 1.8 \mathrm{~g}$; vitamin $\mathrm{B}_{12}, 12 \mathrm{~g} ;$ vitamin $\mathrm{B}_{2}, 6 \mathrm{~g} ;$ vitamin $\mathrm{B}_{6}, 2.8 \mathrm{~g}$; vitamin $\mathrm{D}_{3}$, $2.000 .000 \mathrm{Ul}$; vitamin $\mathrm{E}, 15 \mathrm{~g}$; vitamin $\mathrm{K}_{3}, 1.8 \mathrm{~g}$; Se, $300 \mathrm{mg}$; butylatedhydroxytoluene, $500 \mathrm{mg}$.

${ }^{\sharp}$ Sodiumsalinomycin $(60 \mathrm{mg} / \mathrm{kg})$.

fldeal protein ratios (aa/Lys) recommended by Rostagno et al. (2005).

\#Values and ratios defined on total amino acid basis. 
Birds were housed in a masonry broiler housed covered with clay tiles. The house was divided in 60 pens, measuring $4.50 \mathrm{~m}^{2}$ each, equipped with one tube feeder and one bell drinker. Continuous lighting $(24 \mathrm{~h}$ of light per day) was provided during the experiments, and brooding, using a $250 \mathrm{~W}$ infrared lamp per pen, was provided until birds were 14 days old.

\section{Experimental design}

In each experiment, 1,200 Cobb 500 male chickens were randomly distributed according to a $5 \times 2$ factorial design (digestible lysine level $x$ diet formulation method), totaling ten treatments with six replicates of 20 birds each. Birds were individually weighed at the beginning of each experiment to establish homogeneous-weight groups.

\section{Diet formulation}

Before formulating the experimental diets, total amino acid levels in corn and soybean meal were determined using HPLC, and were then converted into digestible amino acids using the digestibility coefficients proposed by Rostagno et al. (2005).

The amino acid-supplemented diets consisted of a corn- and soybean-based basal diet formulated to meet the recommended nutritional requirements in each phase (Rostagno et al., 2005), with the exception of lysine. L-lysine $\mathrm{HCl}(78.5 \%)$ was then added to the basal diet at the expense of L-glutamic acid and corn starch, resulting in isoenergetic and isonitrogenous diets with increasing digestible lysine levels in each phase. The other essential amino acids were supplemented so their ratios to lysine exceeded the ideal protein ratio (Rostagno et al., 2005) in at least 3\% (Tables 1 and 2) to ensure that no other amino acid would be limiting.

Two diets were formulated using the dilution method. One diet contained high crude protein levels and approximately $108 \%$ of the digestible lysine requirements for each phase; the other diet contained enough amino acids to exceed the ideal protein ratios recommended by Rostagno et al. (2005) by at least three percentage points. Other proteinfree isoenergetic diets were formulated and used to sequentially dilute these diets in order to obtain diets with increasing digestible lysine levels in each phase (Tables 3 and 4) identical to those obtained with the amino acid supplementation technique, but with a constant amino acids-to-lysine ratio.

\section{Evaluated parameters and laboratorial analyses}

The following performance parameters were evaluated in each experiment: body weight gain (g), feed intake (g), digestible lysine intake (g), and feed conversion ratio $(\mathrm{g} / \mathrm{g})$.

Protein deposition (g) and body fat (g) were determined by comparative slaughter at the beginning (reference groups) and end of each feeding phase. The reference groups included18 birds (six replicates of three birds each) per experimental group, weighing $\pm 5 \%$ of their initial body weight. At the end of each experiment, three birds per experimental unit, weighing $\pm 5 \%$ average weight were selected, in a total of 180 birds. After submitted to 24-h fasting to completely empty their digestive tract, birds were weighed, sacrificed by asphyxiation with $\mathrm{CO}_{2}$, featherplucked, and weighed again. Absolute feather weight (g) was obtained by the difference between fasted body weight (g) and feather-free bodyweight (g), and relative feather weight (\%) was calculated in relation to fasted body weight.

Carcasses were frozen, after which they were ground in an industrial meat grinder and homogenized. Aliquots were placed in disposable Petri dishes, weighed, and refrozen $\left(-20^{\circ} \mathrm{C}\right)$. Samples were freezedried for $72 \mathrm{~h}\left(-50^{\circ} \mathrm{C}\right.$; $\left.-80 \mathrm{kPa}\right)$, weighed again, and then processed in a micro mill. Feather samples were manually cut with scissors and homogenized, and then submitted to the laboratory, along with carcass samples, for analyses.

Carcass and feather crude fat content was obtained by extraction with petroleum ether in a Soxlet apparatus. Total nitrogen content was quantified in de-fatted samples using the Kjeldahl method (AOAC, 1995).

Body lysine content ( $\mathrm{g}$ ) in the beginning and end of each experiment was obtained by multiplying body protein content (g) by lysine concentration (\%) in body protein, according the following equation: $[(100$-feather\%) $\times 7.5 / 100]+[($ feather\% $\% 1.8) / 100]$. The values 7.5 and $1.8 \%$ refer to lysine percentages in the protein of the feather-free body and in the feathers, respectively, as found in literature (Emmans \& Fisher, 1986; Emmans \& Oldham, 1988; Sklan \& Noy, 2004). Body lysine deposition (g) was calculated as the difference in lysine body content between the beginning and end of each phase.

The efficiency of dietary lysine utilization for growth (\%) during each phase was calculated as the ratio between lysine deposition and digestible lysine intake 
Table 3 - Diets formulated by the dilution method and fed to1- to 8-day-old broilers ${ }^{\dagger}$

\begin{tabular}{|c|c|c|c|c|c|c|c|c|c|c|}
\hline \multirow{2}{*}{ Ingredients (\%) } & \multicolumn{10}{|c|}{ Digestible lysine level (\%) } \\
\hline & \multicolumn{2}{|c|}{0.975} & \multicolumn{2}{|c|}{1.082} & \multicolumn{2}{|c|}{1.189} & \multicolumn{2}{|c|}{1.296} & \multicolumn{2}{|c|}{1.403} \\
\hline Corn & \multicolumn{2}{|c|}{29.229} & \multicolumn{2}{|c|}{32.437} & \multicolumn{2}{|c|}{35.644} & \multicolumn{2}{|c|}{38.843} & \multicolumn{2}{|c|}{42.039} \\
\hline Soybean meal & \multicolumn{2}{|c|}{34.414} & \multicolumn{2}{|c|}{38.191} & \multicolumn{2}{|c|}{41.967} & \multicolumn{2}{|c|}{45.733} & \multicolumn{2}{|c|}{49.496} \\
\hline Dicalcium phosphate & \multicolumn{2}{|c|}{2.068} & \multicolumn{2}{|c|}{2.021} & \multicolumn{2}{|c|}{1.973} & \multicolumn{2}{|c|}{1.926} & \multicolumn{2}{|c|}{1.878} \\
\hline Limestone & \multicolumn{2}{|c|}{0.770} & \multicolumn{2}{|c|}{0.804} & \multicolumn{2}{|c|}{0.837} & \multicolumn{2}{|c|}{0.871} & \multicolumn{2}{|c|}{0.905} \\
\hline Soybean oil & \multicolumn{2}{|c|}{3.433} & & & & & & & & \\
\hline Sodium chloride & & & & & & & & & & \\
\hline Mineral supplement ${ }^{\ddagger}$ & & & & & & & & & & \\
\hline Vitamin supplement ${ }^{\S}$ & & & & & & & & & & \\
\hline Choline chloride (70\%) & & & & & & & & & & \\
\hline Anticoccidial ${ }^{¥}$ & & & & & & & & & & \\
\hline L-lysine $\mathrm{HCl}(78.5 \%)$ & & & & & & & & & & \\
\hline DL-methionine (99\%) & & & & & & & & & & \\
\hline L-threonine (99\%) & & & & & & & & & & \\
\hline Corn starch & & & & & & & & & & \\
\hline Rice husk & & & & & & & & & & \\
\hline Total & & & & & & & & & & \\
\hline $\begin{array}{l}\text { Digestible amino } \\
\text { acids (\%) }\end{array}$ & & aa/Lys & & aa/Lys & & aa/Lys & & aa/Lys & & aa/Lys \\
\hline Crude protein (\%) & 19.01 & & 21.06 & & 23.12 & & 25.17 & & 27.21 & \\
\hline Lysine $(100)^{\ddagger}$ & 0.975 & 100 & 1.082 & 100 & 1.189 & 100 & 1.296 & 100 & 1.403 & 100 \\
\hline Methionine+cystine(71) & 0.726 & 74 & 0.806 & 74 & 0.886 & 74 & 0.965 & 74 & 1.044 & 74 \\
\hline Methionine (39) & 0.494 & 51 & 0.548 & 51 & 0.603 & 51 & 0.657 & 51 & 0.711 & 51 \\
\hline Threonine (65) & 0.668 & 68 & 0.742 & 68 & 0.814 & 68 & 0.887 & 68 & 0.961 & 68 \\
\hline Valine (75) & 0.767 & 79 & 0.851 & 79 & 0.934 & 79 & 1.019 & 79 & 1.102 & 79 \\
\hline Isoleucine (65) & 0.737 & 75 & 0.818 & 75 & 0.898 & 75 & 0.979 & 75 & 1.059 & 75 \\
\hline Tryptophan (16) & 0.210 & 22 & 0.233 & 22 & 0.256 & 22 & 0.279 & 22 & 0.302 & 22 \\
\hline Arginine (105) & 1.207 & 124 & 1.339 & 124 & 1.470 & 124 & 1.603 & 124 & 1.735 & 124 \\
\hline Leucine (108) & 1.392 & 143 & 1.544 & 143 & 1.697 & 143 & 1.849 & 143 & 2.002 & 143 \\
\hline Phenylalanine (63) & 0.841 & 86 & 0.934 & 86 & 1.026 & 86 & 1.118 & 86 & 1.209 & 86 \\
\hline Glycine+serine $(150)^{\#}$ & 1.710 & 161 & 1.897 & 161 & 2.085 & 161 & 2.272 & 161 & 2.459 & 161 \\
\hline
\end{tabular}

${ }^{+}$Calculated composition: metabolizable energy, $2,960 \mathrm{kcal} / \mathrm{kg}$; available $\mathrm{P}, 0.470 \%$; Ca, $0.939 \% ; \mathrm{Na}, 0.223 \%$.

₹Content per kg: Mn, $150 \mathrm{~g} ; \mathrm{Fe}, 100 \mathrm{~g} ; \mathrm{Zn}, 100 \mathrm{~g} ; \mathrm{Cu}, 16 \mathrm{~g} ; \mathrm{l}, 1.5 \mathrm{~g}$.

${ }^{\S}$ Content per kg: folic acid, $1 \mathrm{~g}$; pantothenic acid, $15 \mathrm{~g}$; niacin, $40 \mathrm{~g}$; biotin, $60 \mathrm{mg}$; vitamin $\mathrm{B}_{1^{\prime}} 1.8 \mathrm{~g}$; vitamin $\mathrm{B}_{12^{\prime}} 12 \mathrm{~g}$; vitamin $\mathrm{B}_{2^{\prime}} 6 \mathrm{~g}$; vitamin $\mathrm{B}_{6^{\prime}} 2.8 \mathrm{~g}$; vitamin $\mathrm{D}_{3^{\prime}} 2.000 .000 \mathrm{Ul}$; vitamin $\mathrm{E}, 15 \mathrm{~g}$; vitamin $\mathrm{K}_{3}, 1.8 \mathrm{~g}$; Se, 300 mg; butylatedhydroxytoluene, $500 \mathrm{mg}$.

* Sodium salinomycin $(60 \mathrm{mg} / \mathrm{kg})$.

fldeal protein ratios (aa/Lys) recommended by Rostagno et al. (2005).

"Values and ratios defined on total amino acid basis.

used only for maintenance, according to the following formula: [lysine deposition/(digestible lysine intakedigestible lysine requirement for maintenance) $x$ 100]. A lysine maintenance requirement of $45 \mathrm{mg} / \mathrm{kg}^{0.75} / \mathrm{day}$ was applied, as determined in metabolism trials with sexually-mature roosters (Siqueira et al., 2011).

\section{Statistical analyses}

The assumptions of normality and homoscedasticity were verified and met by the tests of Cramer-Von Mises and Levene, respectively. The data were then submitted to analysis of variance, according to the following statistical model: $Y_{i j(k)}=\mu+L y s_{i}+T_{i}+L y s x T_{i j}+\varepsilon_{i j(k)}$, where $Y_{i j(k)}$ is the observed value for the variable studied, $\mu$ is the effect of the general mean, Lys is the effect of the $i^{\text {th }}$ dietary lysine level, $T$ is the effect of the $j^{\text {th }}$ formulation method, LySX $T_{i j}$ is the effect of the interaction between dietary lysine levels and formulation method, and $\varepsilon_{i j(k)}$ is the experimental error. Subsequently, data were submitted to analysis of regression, with lysine level as independent variable using polynomial models of first and second order. The goodness of fit of the equations obtained with the different models was evaluated considering the significance of the $\mathrm{F}$ test from the regression model and the coefficients of determination $\left(R^{2}\right)$. 
Table 4 - Diets formulated by the dilution method fed to 8- to 22-day-old broilers ${ }^{\dagger}$

\begin{tabular}{|c|c|c|c|c|c|c|c|c|c|c|}
\hline \multirow{2}{*}{ Ingredients (\%) } & \multicolumn{10}{|c|}{ Digestible lysine level (\%) } \\
\hline & \multicolumn{2}{|c|}{0.840} & \multicolumn{2}{|c|}{0.932} & \multicolumn{2}{|c|}{1.024} & \multicolumn{2}{|c|}{1.116} & \multicolumn{2}{|c|}{1.208} \\
\hline Corn & \multicolumn{2}{|c|}{37.253} & \multicolumn{2}{|c|}{41.171} & \multicolumn{2}{|c|}{45.235} & \multicolumn{2}{|c|}{49.299} & \multicolumn{2}{|c|}{53.376} \\
\hline Soybean meal & \multicolumn{2}{|c|}{27.614} & \multicolumn{2}{|c|}{30.518} & \multicolumn{2}{|c|}{33.530} & \multicolumn{2}{|c|}{36.543} & \multicolumn{2}{|c|}{39.565} \\
\hline Dicalcium phosphate & \multicolumn{2}{|c|}{1.949} & \multicolumn{2}{|c|}{1.907} & \multicolumn{2}{|c|}{1.863} & \multicolumn{2}{|c|}{1.819} & \multicolumn{2}{|c|}{1.775} \\
\hline Limestone & \multicolumn{2}{|c|}{0.741} & \multicolumn{2}{|c|}{0.775} & \multicolumn{2}{|c|}{0.811} & \multicolumn{2}{|c|}{0.846} & \multicolumn{2}{|c|}{0.882} \\
\hline Soybean oil & \multicolumn{2}{|c|}{2.863} & & & & & & & & \\
\hline Sodium chloride & 0.4 & & & & & & & & & \\
\hline Mineral supplement ${ }^{\ddagger}$ & & & & & & & & & & \\
\hline Vitamin supplement ${ }^{\S}$ & & & & & & & & & & \\
\hline Choline chloride (70\%) & & & & & & & & & & \\
\hline Anticoccidial ${ }^{*}$ & & & & & & & & & & \\
\hline L-lysine $\mathrm{HCl}(78.5 \%)$ & & & & & & & & & & \\
\hline DL-methionine (99\%) & & & & & & & & & & \\
\hline L-threonine (99\%) & & & & & & & & & & \\
\hline Corn starch & 23. & & & & & & & & & \\
\hline Rice husk & & & & & & & & & & \\
\hline Total & 100 & & & & & & & & & \\
\hline $\begin{array}{l}\text { Digestible amino } \\
\text { acids (\%) }\end{array}$ & & aa/Lys & & aa/Lys & & aa/Lys & & aa/Lys & & aa/Lys \\
\hline Crude protein (\%) & 16.524 & & 18.231 & & 20.002 & & 21.773 & & 23.549 & \\
\hline Lysine $(100)^{\mathrm{f}}$ & 0.840 & 100 & 0.932 & 100 & 1.024 & 100 & 1.116 & 100 & 1.208 & 100 \\
\hline Methionine+cystine(71) & 0.628 & 75 & 0.695 & 75 & 0.763 & 75 & 0.832 & 75 & 0.900 & 75 \\
\hline Methionine (39) & 0.419 & 50 & 0.463 & 50 & 0.509 & 50 & 0.554 & 50 & 0.600 & 50 \\
\hline Threonine (65) & 0.578 & 69 & 0.639 & 69 & 0.702 & 69 & 0.765 & 69 & 0.828 & 69 \\
\hline Valine (75) & 0.663 & 79 & 0.733 & 79 & 0.805 & 79 & 0.878 & 79 & 0.950 & 79 \\
\hline Isoleucine (65) & 0.627 & 74 & 0.693 & 74 & 0.761 & 74 & 0.829 & 74 & 0.898 & 74 \\
\hline Tryptophan (16) & 0.177 & 21 & 0.196 & 21 & 0.215 & 21 & 0.234 & 21 & 0.254 & 21 \\
\hline Arginine (105) & 1.018 & 121 & 1.125 & 121 & 1.236 & 121 & 1.347 & 121 & 1.458 & 121 \\
\hline Leucine (108) & 1.251 & 148 & 1.382 & 148 & 1.518 & 148 & 1.655 & 148 & 1.792 & 148 \\
\hline Phenylalanine (63) & 0.726 & 86 & 0.802 & 86 & 0.882 & 86 & 0.961 & 86 & 1.040 & 86 \\
\hline Glycine+serine $(150)^{\#}$ & 1.479 & 175 & 1.634 & 175 & 1.796 & 175 & 1.957 & 175 & 2.119 & 175 \\
\hline
\end{tabular}

${ }^{\dagger}$ Calculated composition: metabolizable energy, 3,000 kcal/kg; available P, 0.442\%; Ca, 0.884\%; Na, 0.214\%.

${ }^{\ddagger}$ Content per kg: Mn, $150 \mathrm{~g} ; \mathrm{Fe}, 100 \mathrm{~g} ; \mathrm{Zn}, 100 \mathrm{~g} ; \mathrm{Cu}, 16 \mathrm{~g} ; \mathrm{l}, 1.5 \mathrm{~g}$.

§ Content per kg: folic acid, $1 \mathrm{~g}$; pantothenic acid, $15 \mathrm{~g}$; niacin, $40 \mathrm{~g}$; biotin, 60 mg; vitamin $\mathrm{B}_{1^{\prime}} 1.8 \mathrm{~g}$; vitamin $\mathrm{B}_{12^{\prime}} 12 \mathrm{~g} ;$ vitamin $\mathrm{B}_{2}, 6 \mathrm{~g}$; vitamin $\mathrm{B}_{6^{\prime}} 2.8 \mathrm{~g}$; vitamin $\mathrm{D}_{3^{\prime}} 2.000 .000 \mathrm{Ul}$; vitamin $\mathrm{E}, 15 \mathrm{~g}$; vitamin $\mathrm{K}_{3}, 1.8 \mathrm{~g}$; Se, $300 \mathrm{mg}$; butylatedhydroxytoluene, $500 \mathrm{mg}$.

* Sodium salinomycin $(60 \mathrm{mg} / \mathrm{kg})$.

fldeal protein ratios (aa/Lys) recommended by Rostagno et al. (2005).

\#Values and ratios defined on total amino acid basis.

A parallelism test was performed to compare the equation parameters for each diet formulation technique when there was an effect of lysine level and technique. The formulation technique ( $T$ ) was the classificatory variable, and digestible lysine dietary level (Lys) was the co-variable, according to the model adapted from Kaps and Lamberson (2004): $\hat{Y}_{i j}=\beta_{0}+T_{i}+\beta_{1}$ $x$ Lys $s_{i j}+\Sigma_{i} \beta_{2 i} x(T x L y s)_{i j}+\beta_{3} x L y s_{i j}{ }^{2}+\Sigma_{i j} \beta_{4 i} x(T x L y s)_{i j}{ }^{2}+\varepsilon_{i j}$, where $\hat{Y}_{i j}$ is the variable value corresponding to observation $j$ of method $i_{i} T_{i}$ is the effect of the formulation technique; $\beta_{\alpha} \beta_{1}, \beta_{2,} \beta_{3}$ and $\beta_{4 i}$ are the regression parameters; (TxLyS) ij is the effect of the interaction between the classificatory variable and the co-variable for the linear component; $(T x L y s)_{i j}{ }^{2}$ is the effect of the interaction between the classificatory variable and co-variable for the quadratic component; and $\varepsilon_{i j}$ is the random error associated with observation $j$ of technique $i$. Statistical analyses were performed $(\mathrm{P}<0.05)$ using SAS 9.0 software (2002).

\section{RESULTS}

During the pre-starter phase, lysine intake (Lysl), body weight gain (BWG) and feed conversion ratio (FCR) responses to increasing lysine levels were independent of diet formulation technique. Interactions 
among lysine levels and formulation techniques for the deposition of protein (PD), fat (FD), lysine (LysD) and efficiency of lysine utilization (ELys) were observed. Feed intake (FI) and relative feather weight (RFW) were not affected ( $p>0.05$ ) by lysine level or diet formulation technique (Table 5).

The equations, adjusted for the different variables, $\mathrm{F}$ test significance, coefficients of determination $\left(R^{2}\right)$, and optimal digestible lysine levels (OLys) ofpre-starter broiler diets are presented in Table 6 .

Lysine intake (Lysl) and BWG of the birds were not affected ( $p>0.05$ ) by diet formulation technique, and linearly increased with lysine levels.

Considering the effects of lysine levels and formulation technique on FCE, the parallelism test was performed. Differences were detected $(p<0.05)$ only between the constants $\left(\beta_{0}\right)$ of the individual equations, showing that the formulation technique did not influence the shape of FCR responses; nevertheless, the magnitude of these responses was different.

The level of digestible lysine estimated to improve bird FCR, irrespective of the formulation technique, was $1.361 \%(0.460 \% / M c a l M E)$; however, it was observed that the diet dilution technique potentiated the FCR responses $(1.115 \mathrm{~g} / \mathrm{g})$, presenting $3.4 \%$ better values than the amino acid supplementation technique (1.154 g/g).

PD, FD, LysD, and ELys responses, as a function of dietary lysine levels, varied according to the formulation technique, highlighting the need to apply different equations for each technique. PD, LysD and Elys responses to supplementation technique

Table 5 - Feed intake (FI), digestible lysine intake (Lysl), body weight gain (BWG), feed conversion ratio (FCR), protein (PD), fat (FD) and lysine (LySD) depositions, efficiency of lysine utilization (ELys) and relative feather weight (RFW) of broilers during the pre-starter phase ( 1 to 8 days old)

\begin{tabular}{|c|c|c|c|c|c|c|c|c|c|c|c|}
\hline \multirow[b]{2}{*}{ Variable } & \multirow{2}{*}{$\begin{array}{l}\text { Formulation } \\
\text { technique }^{+}\end{array}$} & \multicolumn{5}{|c|}{ Digestible lysine level (\%) } & \multirow[b]{2}{*}{ General } & \multirow{2}{*}{$\begin{array}{l}C V \\
(\%)\end{array}$} & \multicolumn{3}{|c|}{$p>F^{\ddagger}$} \\
\hline & & 0.975 & 1.082 & 1.189 & 1.296 & 1.403 & & & Lysine & Technique & $\begin{array}{c}\text { Lys } \mathrm{x} \\
\text { Technique }\end{array}$ \\
\hline \multirow{3}{*}{$\mathrm{FI}(\mathrm{g})$} & $S$ & 171.53 & 177.71 & 172.67 & 177.32 & 177.41 & 175.33 & \multirow{3}{*}{6.11} & \multirow{3}{*}{0.9526} & \multirow{2}{*}{0.7886} & \multirow{2}{*}{0.2322} \\
\hline & $\mathrm{D}$ & 179.07 & 172.56 & 179.26 & 168.18 & 173.85 & 174.59 & & & & \\
\hline & General & 175.30 & 175.14 & 175.96 & 172.75 & 175.63 & & & & & \\
\hline \multirow{3}{*}{ Lysl (g) } & $\mathrm{S}$ & 1.673 & 1.923 & 2.053 & 2.298 & 2.489 & 2.087 & \multirow{3}{*}{6.22} & \multirow{3}{*}{$\leq 0.0001$} & \multirow{3}{*}{0.6677} & \multirow{3}{*}{0.2653} \\
\hline & $\mathrm{D}$ & 1.746 & 1.867 & 2.132 & 2.180 & 2.439 & 2.073 & & & & \\
\hline & General & 1.709 & 1.895 & 2.092 & 2.239 & 2.464 & & & & & \\
\hline \multirow{3}{*}{ BWG (g) } & $\mathrm{S}$ & 138.19 & 148.11 & 149.99 & 150.63 & 151.52 & 147.69 & \multirow{2}{*}{5.96} & \multirow{2}{*}{0.0028} & \multirow{2}{*}{0.0687} & \multirow{2}{*}{0.3051} \\
\hline & D & 146.19 & 145.04 & 159.44 & 149.89 & 159.33 & 151.98 & & & & \\
\hline & General & 142.19 & 146.57 & 154.71 & 150.26 & 155.43 & & & & & \\
\hline \multirow{3}{*}{$\mathrm{FCR}(\mathrm{g} / \mathrm{g})$} & $\mathrm{S}$ & 1.243 & 1.201 & 1.153 & 1.179 & 1.173 & 1.190 & \multirow{3}{*}{4.77} & \multirow{3}{*}{$\leq 0.0001$} & \multirow{3}{*}{0.0096} & \multirow{3}{*}{0.4939} \\
\hline & $\mathrm{D}$ & 1.227 & 1.190 & 1.125 & 1.122 & 1.091 & 1.151 & & & & \\
\hline & General & 1.235 & 1.196 & 1.139 & 1.151 & 1.132 & & & & & \\
\hline \multirow{3}{*}{$\mathrm{PD}(\mathrm{g})$} & $S$ & 16.97 & 19.62 & 20.48 & 20.52 & 19.89 & 19.50 & \multirow{2}{*}{7.35} & \multirow{2}{*}{$\leq 0.0001$} & 1991 & 00114 \\
\hline & D & 18.93 & 18.84 & 18.84 & 21.77 & 21.61 & 20.00 & & & & \\
\hline & General & 17.95 & 19.23 & 19.66 & 21.14 & 20.75 & & & & & \\
\hline & $S$ & 7.46 & 8.32 & 8.47 & 7.81 & 9.27 & 8.27 & & & م01090 & $<0 \Omega 0 \cap 1$ \\
\hline FD (g) & $D$ & 11.95 & 8.81 & 9.40 & 9.84 & 6.65 & 9.33 & $1 / .11$ & 0.1121 & 0.0109 & $\leq 0.0001$ \\
\hline & General & 9.70 & 8.56 & 8.94 & 8.83 & 7.96 & & & & & \\
\hline $14 c \cap / g)$ & S & 1.272 & 1.471 & 1.534 & 1.541 & 1.495 & 1.460 & 737 & $<00001$ & 1877 & \\
\hline LysD (g) & $\mathrm{D}$ & 1.423 & 1.411 & 1.412 & 1.638 & 1.624 & 1.487 & 1.31 & $\leq 0.0001$ & $0.18 / 2$ & $0.01 / 0$ \\
\hline & General & 1.348 & 1.438 & 1.473 & 1.590 & 1.559 & & & & & \\
\hline Flyc§ (\%) & $S$ & 79.06 & 80.90 & 77.14 & 67.90 & 61.52 & 73.22 & 578 & $<00001$ & 00465 & $<0 \cap 0 \cap 1$ \\
\hline ELyS & D & 84.81 & 78.44 & 68.41 & 77.78 & 68.76 & 75.57 & 5.18 & $\leq 0.0001$ & 0.0465 & $\leq 0.0001$ \\
\hline & General & 81.93 & 79.56 & 72.78 & 72.84 & 65.14 & & & & & \\
\hline REW (\%) & $S$ & 2.29 & 2.22 & 2.28 & 2.04 & 1.98 & 2.14 & & & & \\
\hline RFV (\%) & $D$ & 1.94 & 2.32 & 2.28 & 1.84 & 1.95 & 2.06 & 15.72 & 0.0634 & 0.3609 & 0.3411 \\
\hline & General & 2.11 & 2.22 & 2.28 & 1.94 & 1.96 & & & & & \\
\hline
\end{tabular}

${ }^{\dagger} \mathrm{S}=$ supplementation technique; $\mathrm{D}=$ dilution technique.

${ }^{\ddagger} F$ test of ANOVA.

$\S_{\text {ELys }}=$ LysD (mg/day)/(LysI (mg/day)-Lys $\left(m g /\right.$ day)) $\times 100 ;$ where Lys $_{m}=45$ mg/kg ${ }^{0.75}$ per day. 
Table 6 - Adjusted equations, F test significance, coefficients of determination $\left(R^{2}\right)$ and optimal digestible lysine levels (OLys) in pre-starter ( 1 to 8 days old) broiler diets

\begin{tabular}{|c|c|c|c|c|}
\hline Model & Variable / Equation & $p>F$ & $R^{2}$ & OLys (\%) \\
\hline & Digestible lysine intake (g) & & & \\
\hline \multirow[t]{2}{*}{ Linear } & LysI $=0.020+1.733 x$ Lys & $\leq 0.0001$ & 0.997 & ------ \\
\hline & Body weight gain $(\mathrm{g})$ & & & \\
\hline \multirow[t]{2}{*}{ Linear } & BWG $=116.326+28.181 x$ Lys & $\leq 0.0001$ & 0.732 & ------ \\
\hline & Feed conversion ratio ${ }^{\dagger}(\mathrm{g} / \mathrm{g})$ & & & \\
\hline \multirow[t]{2}{*}{ Quadratic } & $F C R=2.422(-0.039)-1.864 x$ Lys +0.685 Lys $^{2}$ & $\leq 0.0001$ & 0.866 & 1.361 \\
\hline & Protein deposition $(\mathrm{g})-\mathrm{S}$ & & & \\
\hline \multirow[t]{2}{*}{ Quadratic } & $P D=-51.939+115.538 x$ Lys $-45.902 x$ Lys $^{2}$ & 0.0015 & 0.986 & 1.259 \\
\hline & Protein deposition $(\mathrm{g})-\mathrm{D}$ & & & \\
\hline \multirow[t]{2}{*}{ Linear } & $P D=10.946+7.583 x$ Lys & $\leq 0.0001$ & 0.718 & ------ \\
\hline & Fat deposition $(\mathrm{g})-\mathrm{S}$ & & & \\
\hline \multirow[t]{2}{*}{------ } & $F D=8.266$ & ------ & ------ & ------ \\
\hline & Fat deposition $(\mathrm{g})-\mathrm{D}$ & & & \\
\hline \multirow[t]{2}{*}{ Linear } & $F D=19.975-8.953 x$ Lys & 0.0002 & 0.623 & ------ \\
\hline & Lysine deposition $(\mathrm{g})-\mathrm{S}$ & & & \\
\hline \multirow[t]{2}{*}{ Quadratic } & LysD $=-3.851+8.580 x$ Lys $-3.403 x_{L^{2} y s^{2}}$ & 0.0015 & 0.986 & 1.261 \\
\hline & Lysine deposition (g) - D & & & \\
\hline \multirow[t]{2}{*}{ Linear } & LysD $=0.816+0.575 x$ Lys & $\leq 0.0001$ & 0.704 & ------ \\
\hline & Efficiency of lysine utilization (\%) - S & & & \\
\hline \multirow[t]{2}{*}{ Quadratic } & ELys $=-65.552+283.322 x$ Lys $-137.810 x_{\text {Lys }}^{2}$ & $\leq 0.0001$ & 0.973 & 1.027 \\
\hline & Efficiency of lysine utilization (\%) - D & & & \\
\hline Linear & ELys $=112.907-31.500 x$ Lys & 0.0002 & 0.572 & ------ \\
\hline
\end{tabular}

${ }^{\top}$ The number in brackets must be subtracted to obtain the specific equation for the dilution technique. $S=$ supplementation technique; $D=$ dilution technique.

were curvilinear, and FD was not affected by dietary lysine levels ( $p>0.05$ ). Maximum points calculated for PD, LysD and ELys were 1.259, 1.261 and 1.027\%, respectively. Moreover, the dilution technique linearly increased PD and LysD and decreased FD and ELys, as dietary lysine levels increased.

During the starter phase, lysine levels influenced Lysl, BWG, FCR, PD, LysD and ELys, irrespective the formulation technique, with an interaction observed for FD and RFW. Feed intake was not affected ( $p>0.05$ ) by lysine levels or diet formulation technique (Table 7).

The equations, adjusted for the different variables, $\mathrm{F}$ testsignificance, coefficients of determination $\left(R^{2}\right)$, and optimal digestible lysine levels (OLys) of starter phase diets are shown in Table 8.

Diet formulation technique did not influence Lysl ( $p>0.05$ ), but it linearly increased with increasing dietary lysine levels. Body weight gain was not influenced ( $p>0.05)$ by formulation technique, and presented a quadratic behavior in response to increasing dietary lysine levels. The maximum BWG response estimated based on the quadratic equation was $647.03 \mathrm{~g}$, corresponding to a digestible lysine level of $1.171 \%$.
Diet formulation technique and dietary lysine levels influenced FCR, but no interaction was observed between these factors, suggesting that their effects were independent. However, the test comparing the equation parameters $\left(\beta_{0}, \beta_{1}\right.$ and $\beta_{2}$ ) of each technique detected differences between the constants $\left(\beta_{0}\right)$ and the linear parameters $\left(\beta_{1}\right)$, indicating that the shape and magnitude of the FCR responses varied with the diet formulation technique, despite the absence of an interaction between factors.

When diets were diluted, increasing dietary lysine levels produced gradual reduction of FCR values. The best response $(1.420 \mathrm{~g} / \mathrm{g})$ was obtained with an estimated digestible lysine value of $1.187 \%$, which is higher than the $1.140 \%$ level required to optimize FCR response $(1.478 \mathrm{~g} / \mathrm{g})$ using the amino acid supplementation technique.

Protein deposition and LysD were not affected ( $p>0.05$ ) by the diet formulation technique, but linearly increased in response to increasing dietary lysine levels.

The interaction (lysine $x$ technique) obtained for FD showed that the behavior of this parameter depends on the formulation technique. Using the supplementation technique, FD was not affected ( $p>0.05)$ by lysine 
Table 7 - Feed intake (FI), digestible lysine intake (Lysl), body weight gain (BWG), feed conversion ratio (FCR), protein (PD), fat (FD) and lysine (LysD) depositions, efficiency of lysine utilization (ELys) and relative feather weight (RFW) of broilers during the starter phase (8 to 22 days old)

\begin{tabular}{|c|c|c|c|c|c|c|c|c|c|c|c|}
\hline \multirow[b]{2}{*}{ Variable } & \multirow{2}{*}{$\begin{array}{l}\text { Formulation } \\
\text { technique }^{\dagger}\end{array}$} & \multicolumn{5}{|c|}{ Digestible lysine level (\%) } & \multirow[b]{2}{*}{ General } & \multirow{2}{*}{$\begin{array}{l}\text { CV } \\
(\%)\end{array}$} & \multicolumn{3}{|c|}{$\mathrm{p}>\mathrm{F}^{\ddagger}$} \\
\hline & & 0.840 & 0.932 & 1.024 & 1.116 & 1.208 & & & Lysine & Technique & $\begin{array}{c}\text { Lys } \mathrm{x} \\
\text { Technique }\end{array}$ \\
\hline \multirow{3}{*}{$\mathrm{FI}(\mathrm{g})$} & $S$ & 938.50 & 923.33 & 943.59 & 950.43 & 942.85 & 939.74 & \multirow{2}{*}{3.58} & \multirow{2}{*}{0.5685} & \multirow{2}{*}{0.1977} & \multirow{2}{*}{0.9567} \\
\hline & D & 921.42 & 924.15 & 925.55 & 942.17 & 929.00 & 928.46 & & & & \\
\hline & General & 929.96 & 923.24 & 934.57 & 946.30 & 935.93 & & & & & \\
\hline \multirow{3}{*}{ Lysl (g) } & $S$ & 7.883 & 8.607 & 9.662 & 10.607 & 11.390 & 9.630 & \multirow{3}{*}{3.52} & \multirow{3}{*}{$\leq 0.0001$} & \multirow{3}{*}{0.1902} & \multirow{3}{*}{0.9600} \\
\hline & D & 7.740 & 8.613 & 9.478 & 10.515 & 11.223 & 9.514 & & & & \\
\hline & General & 7.812 & 8.610 & 9.570 & 10.561 & 11.307 & & & & & \\
\hline \multirow{3}{*}{ BWG (g) } & $S$ & 555.57 & 588.85 & 632.60 & 640.96 & 633.31 & 610.26 & \multirow{2}{*}{3.03} & \multirow{2}{*}{$\leq 0.0001$} & \multirow{2}{*}{0.1246} & \multirow{2}{*}{0.4168} \\
\hline & D & 555.26 & 597.44 & 627.13 & 654.03 & 654.92 & 617.75 & & & & \\
\hline & General & 555.41 & 593.14 & 629.86 & 647.50 & 644.11 & & & & & \\
\hline \multirow{3}{*}{ FCR (g/g) } & $S$ & 1.653 & 1.570 & 1.492 & 1.483 & 1.488 & 1.533 & \multirow{3}{*}{2.73} & \multirow{3}{*}{$\leq 0.0001$} & \multirow{3}{*}{0.0104} & \multirow{3}{*}{0.2659} \\
\hline & D & 1.659 & 1.547 & 1.476 & 1.441 & 1.419 & 1.508 & & & & \\
\hline & General & 1.657 & 1.558 & 1.484 & 1.462 & 1.454 & & & & & \\
\hline \multirow{3}{*}{$\mathrm{PD}(\mathrm{g})$} & $S$ & 90.31 & 92.64 & 99.83 & 103.60 & 104.54 & 98.18 & \multirow{2}{*}{6.22} & \multirow{2}{*}{$\leq 0.0001$} & 04445 & 02384 \\
\hline & D & 84.71 & 97.24 & 95.02 & 104.43 & 103.48 & 96.98 & & & 0.4445 & 0.2384 \\
\hline & General & 87.51 & 94.94 & 97.42 & 104.02 & 104.01 & & & & & \\
\hline FD (a) & $S$ & 56.89 & 60.69 & 63.75 & 58.90 & 58.93 & 59.83 & 1006 & $<00001$ & 01059 & $<00001$ \\
\hline ID (y) & $D$ & 68.13 & 67.44 & 57.83 & 47.19 & 46.04 & 57.33 & 10.00 & $\leq 0.0001$ & 0.1050 & - \\
\hline & General & 62.51 & 64.06 & 60.79 & 53.05 & 52.48 & & & & & \\
\hline J $v s D(a)$ & $S$ & 6.634 & 6.864 & 7.347 & 7.633 & 7.712 & 7.238 & 60 & $<0 \cap 0 \cap 1$ & 8556 & 03938 \\
\hline LysD (g) & D & 6.327 & 7.187 & 7.119 & 7.756 & 7.699 & 7.218 & 0.02 & $\leq 0.0001$ & .0350 & 0.3930 \\
\hline & General & 6.480 & 7.026 & 7.233 & 7.695 & 7.706 & & & & & \\
\hline Elvs§ (\%) & $S$ & 87.80 & 82.85 & 78.73 & 74.32 & 69.79 & 78.70 & 591 & $<00001$ & 0.5802 & 0.4665 \\
\hline & D & 85.20 & 86.92 & 77.77 & 76.14 & 70.82 & 79.37 & 3.91 & $\leq 0.0001$ & 0.5802 & 0.4005 \\
\hline & General & 86.50 & 84.88 & 78.25 & 75.23 & 70.30 & & & & & \\
\hline REW (\%) & $S$ & 3.95 & 3.06 & 3.79 & 3.69 & 3.54 & 3.61 & 1999 & 05275 & $<0 \cap \cap \cap 1$ & 00005 \\
\hline$n \Gamma v(\%)$ & D & 2.22 & 3.36 & 1.90 & 2.84 & 2.65 & 2.59 & 19.99 & $0.52 \angle 3$ & -0.0001 & 0.0005 \\
\hline & General & 3.09 & 3.21 & 2.84 & 3.26 & 3.10 & & & & & \\
\hline
\end{tabular}

${ }^{\dagger} \mathrm{S}=$ supplementation technique; $\mathrm{D}=$ dilution technique.

${ }^{\ddagger} F$ test of ANOVA.

$\S_{\text {ELys }}=$ LysD $\left(\mathrm{mg} /\right.$ day)/(Lysl (mg/day)-Lys $\left(\mathrm{mg} /\right.$ day)) $\times 100 ;$ where Lys $\mathrm{m}_{\mathrm{m}}=45 \mathrm{mg} / \mathrm{kg}^{0.75}$ per day.

levels; however, when the dilution technique was used, it linearly decreased.

Considering the starter phase, diet formulation technique did not affect Elys ( $p>0.05)$, which was linearly reduced in response to increasing dietary lysine levels. Although there was an interaction between factors relative to RFW, it was not possible to adjust any of the regression models for the formulation techniques evaluated.

\section{DISCUSSION}

D'Mello (1982) compared broiler responses to increasing dietary lysine levels using amino acid supplementation (Boomgaardt \& Baker, 1973) and diet dilution (Gous, 1980) and found that both techniques resulted in similar weight gains. In the present study, the absence of formulation technique effects on $\mathrm{Fl}$ and BWG confirmed the equivalent effect of techniques during both rearing phases; however, there was no equivalence for the other evaluated parameters.

In the pre-starter phase, FCR responses provided identical lysine level estimates (1.361\%) for both formulation techniques; however, the magnitude of these responses was different, with the diluted diets showing a $3.4 \%$ improvement in FCR compared with the supplemented diets. Using the equation set for Lysl, the estimate of $1.361 \%$ corresponded to a lysine in take of $340 \mathrm{mg} /$ day for the first eight days. This is consistent with Rostagno et al. (2005), who 
Table 8 - Adjusted equations, F test significance, coefficients of determination $\left(R^{2}\right)$ and optimal digestible lysine levels (OLys) in starter (8 to 22 days old) broiler diets

\begin{tabular}{|c|c|c|c|c|}
\hline Model & Variable / Equation & $P>F$ & $\mathrm{R}^{2}$ & OLys (\%) \\
\hline & Digestible lysine intakel (g) & & & \\
\hline \multirow[t]{2}{*}{ Linear } & LysI $=-0.380+9.718 x$ Lys & $\leq 0.0001$ & 0.995 & ------ \\
\hline & Body weight gain (g) & & & \\
\hline \multirow[t]{2}{*}{ Quadratic } & BWG $=-525.992+2002.911 \times$ Lys $-854.980 x^{2}$ Ls $^{2}$ & $\leq 0.0001$ & 0.992 & 1.171 \\
\hline & Feed conversion ratio $(\mathrm{g} / \mathrm{g})$ & & & \\
\hline \multirow[t]{2}{*}{ Quadratic } & $F C R=4.021(+0.160)-4.463(-0.187) \times L y s+1.958 x L^{2} y s^{2}$ & $\leq 0.0001$ & 0.995 & $\begin{array}{l}1.140 \text { (S) } \\
1.187 \text { (D) }\end{array}$ \\
\hline & Protein deposition (g) & & & \\
\hline \multirow[t]{2}{*}{ Linear } & $P D=50.742+45.740 x$ Lys & $\leq 0.0001$ & 0.926 & ------ \\
\hline & Fat deposition (g) - S & & & \\
\hline \multirow[t]{2}{*}{------ } & $F D=59.832$ & ------ & ------ & ------ \\
\hline & Fat deposition $(\mathrm{g})-\mathrm{D}$ & & & \\
\hline \multirow[t]{2}{*}{ Linear } & $F D=129.033-70.027 x$ Lys & $\leq 0.0001$ & 0.924 & ------ \\
\hline & Lysine deposition (g) & & & \\
\hline \multirow[t]{2}{*}{ Linear } & Lys $D=3.755+3.391 \times$ Lys & $\leq 0.0001$ & 0.931 & ------ \\
\hline & Efficiency of lysine utilization (\%) & & & \\
\hline Linear & ELys $=125.835-45.704 x$ Lys & $\leq 0.0001$ & 0.975 & ------ \\
\hline
\end{tabular}

${ }^{\dagger}$ The number in brackets must be added or subtracted to obtain the specific equation for the dilution technique.

$S=$ supplementation technique; $\mathrm{D}=$ dilution technique.

recommended $1.363 \%$ (328 mg/day) lysine for broiler chickens during the first seven days of life.

The curvilinear responses of PD and LysD obtained with the supplementation technique suggest that these protein and lysine deposition may have been limited by another amino acid, which became limiting when L-lysine $\mathrm{HCl}$ was added to the experimental diets. Although glycine and serine are considered nonessential amino acids (D'Mello, 2003), studies indicate that glycine can be conditionally essential for broilers, especially during the early stages of life, when vegetable diets supplemented with crystalline amino acids are used (Corzo et al., 2004; Dean et al., 2006). Corzo et al. (2004) reported the specific needs of dietary glycine and suggested that the transamination of amino acids, such as threonine or serine to glycine, could be metabolically inefficient to meet the glycine requirements. Therefore, it is possible that PD and LysD responses to the supplementation technique were caused by total glycine+serine deficiency, particularly in the diets containing 1.296 and $1.403 \%$ of digestible lysine (Table 1).

On the other hand, when the diets were formulated by the dilution technique (Table 3), the ratio of lysine to glycine+serine in the experimental diets (161\%) remained constant among treatments and was higher than that recommended for broiler chickens during the pre-starter phase (150\%). Therefore, it is unlikely that glycine+serine deficiencies affected PD and LysD responses, which is confirmed by the increasing linear behavior of these variables.

Increasing levels of a given limiting amino acid in the diet can change weight gain composition, reducing fat deposition in broilers (Jones, 1986; Leclercq, 1998; Gous, 1998; 2007). The results obtained during the pre-starter phase of the present study confirm this hypothesis only when the diet dilution technique was used. Lysine levels did not affect feather deposition of the birds fed diets formulated by the supplementation technique.

The factors that influence amino acid utilization efficiency have been extensively reviewed by Heger \& Frydrych (1989), who indicated that the relative concentration of the limiting amino acid in the diet as the main factor affecting efficiency. At suboptimal in take levels, amino acids are more efficiently used and only a small fraction is broken down. As the concentration of the limiting amino acid in the diet increases, its utilization efficiency decreases because a greater proportion is directed to alternative metabolic processes, unrelated to protein deposition (Heger \& Frydrych, 1989). This may explain the reduced Elys observed with increasing lysine levels in the present study.

In general, birds fed dilution-formulated diets used lysine more efficiently $(75.57 \%)$ than those fed supplementation-formulated diets (73.22\%). This sup- 
ports the better FCR responses of pre-starter broilers fed dilution-formulated diets. Amino acid ratios varied among diets formulated with the supplementation technique, while the diluting technique maintained these ratios constant, which corroborates the fact that dietary amino acid may affect the utilization efficiency of the first limiting factor, as reported by Heger \& Frydrych (1989).

The diet dilution technique improved broiler performance potential, as shown by the best FCR responses, by FD reduction and by the increasing linear PD and LysD behavior responses. The digestible lysine level of $1.361 \%(0.460 \% / M c a l ~ M E)$, estimated on FCR-basis, was adequate to meet the requirements of Cobb 500 broilers during the pre-starter phase (1 to 8 days). This corresponds to $2.38 \mathrm{~g}$ (340 mg/day) lysine intake during this period.

Statistically, the FCR results obtained fort he starter phase demonstrated that the analysis of variance was not able to explore the quantitative data, as discussed by Pesti et al. (2009). Therefore, it is necessary to use methods capable of exploring the effects of qualitative factors (formulation technique) on the responses of quantitative factors (digestible lysine levels). In this study, the model adapted from Kaps \& Lamberson (2004) was adequate for this purpose, detecting differences in the behavior of the responses to the formulation techniques in the absence of interactions between the studied factors, allowing a detailed analysis of the FCR responses.

For the starter phase, FCR responses obtained with the supplementation technique ceased before those observed with the dilution technique, showing that diluted diets enhanced broiler performance potential. Therefore, in a dilution-formulated diet, it is estimated that $1.187 \% \quad(11.16 \mathrm{~g} /$ day $)$ digestible lysine are required to supply FCR requirements of broilers during the starter phase.

The FD results obtained during the starter phase are according to those verified during the pre-starter phase. Feather deposition reduced as a function of dietary lysine levels only when the dilution technique was used, with no effect of lysine levels the FD when diets were formulated by supplementation.

Assuming that the diets obtained by the supplementation and dilution techniques presented different amino acid balance, and taking into account that this balance is one of the main factors affecting the efficiency of the utilization of limiting amino acids (Heger \& Frydrych, 1989), the absence of formulation technique effects on the Elys during the starter phase was not expected, although our results confirmed the effect of lysine levels on ELys during the pre-starter phase.

The effects of the diet formulation technique on $\mathrm{FI}$, Lysl, BWG, FCR, and FD during the starter phase (8 to 22 days) were, in general, consistent with those observed during the pre-starter phase (1 to 8 days). However, PD, LysD, and ELys responses were not affected by formulation technique during the starter phase, in contrast with the results obtained during the pre-starter phase. These observations suggest that the developmental stage of the birds has an effect on tolerance to variations in dietary amino acid balance. Nevertheless, FCR and FD results during the starter phase may support arguments favoring the application of the diet-dilution technique.

The estimated lysine level of $1.187 \%(0.395 \% /$ Mcal ME), based on FCR, best met the requirements of Cobb 500 broilers during the starter phase. This level corresponded to11.16 g or $797 \mathrm{mg} /$ day of lysine intake, in agreement with Rostagno et al. (2005), who recommended $797 \mathrm{mg} /$ day or $1.189 \%$ of digestible lysine for8- to 21-day-old broilers.

In general, our results suggested that the diet dilution technique favored the performance potential of broilers. This contrasts with the results of other authors, who observed equivalent results using both techniques. Considering that experimental diets formulated using dilution normally require a limited inclusion of crystalline amino acids, and considering that the cost of these amino acids often hinders protein nutrition studies, we suggest that using the dilution technique to determine broiler lysine requirements could allow producing economically viable experimental diets.

\section{ACKNOWLEDGEMENTS}

The authors gratefully acknowledge the financial support of Fundação de Amparo a Pesquisa do Estado de São Paulo (FAPESP, Brazil), the grants provided by Conselho Nacional de Desenvolvimento Científico e Tecnológico (CNPQ, Brazil) and the synthetic amino acids donated by Ajinomoto Biolatina Indústria e Comércio LTDA.

\section{REFERENCES}

Association of Official Analytical Chemists. Official methods of analysis. $16^{\text {th }}$ ed. Arlington; 1995

Baker DH, Han Y. Ideal amino acid profile for chickens during the first three weeks post hatching. Poultry Science 1994;73:1441-1447. 
Boomgaardt J, Baker DH. The lysine requirement of growing chicks feed sesame meal-gelatin diets at three protein levels. Poultry Science 1973;52:586-595.

Corzo A, Kidd MT, Burnham DJ, Kerr BJ. Dietary glycine needs of broiler chicks. Poultry Science 2004;83:1382-1384.

D'Mello JPF. A comparison of two empirical methods of determining amino acid requirements. World's Poultry Science Journal 1982;38:114-119.

D'Mello JPF. Responses of growing poultry to amino acids. In: D'Mello JPF, editor. Amino acid in animal nutrition. Wallingford, UK: CABI Publishing; 2003. p.237-262.

Dean DW, Bidner TD, Southern LL. Glycine supplementation to low protein, amino acids-supplemented diet supports optimal performance of broiler chicks. Poultry Science 2006; 85:288-296.

Emmans GC, Fisher C. Problems in nutritional theory. In C Fisher and $\mathrm{K}$ Boorman, editors. Nutrient requirements of poultry and nutritional research. London: Butterwordths; 1986. p.9-39.

Emmans GC, Oldham JD. Modelling of growth and nutrition in different species. In: Korver S, Van Arendonk JAM, editors. Modelling of livestock production systems. Amsterdam: Kluwer Academic Publishers; 1988. p.13-21.

Fisher C, Morris TR. The determination of the methionine requirements of laying pullets by a diet dilution technique. British Poultry Science 1970;11:67-82.

Gous RM. An improved method for measuring the response of broiler chickens to increasing dietray concentrations of an amino acid. Proceedings of the $6^{\text {nd }}$ European Poultry Conference; 1980; Hamburg. Alemanha. p. 32-39.

Gous RM. Methodologies for modeling energy and amino acid responses in poultry. Revista Brasileira de Zootecnia 2007;36:263-275.

Gous RM. An improved method for measuring the response of broiler chickens to increasing dietray concentrations of an amino acid. Proceedings of the $6^{\text {th }}$ European Poultry Conference; 1980; Hamburg. Alemanha. v.3, p.32-39.
Heger J, Frydrych Z. Efficiency of utilization of amino acids. In M Friedman editor. Absorption and utilization of amino acids. Boca Raton: CRC Press; 1989. p. 31-56.

JONES RL. Nutritional influences on carcass composition in the broiler chicken. Proceedings of the Nutrition Society 1986;45:27-32.

Kaps M, Lamberson WR. Biostatistics for animal science. Wallingford: CABI Publishing; 2004

Leclerq B. Specific effects of lysine on broiler production: comparison with threonine and valine. Poultry Science 1998;77:118-123.

Moughan PJ, Fuller MF. Modelling amino acids metabolism and the estimation of amino acids requirements. In: D'Mello JPF editor. Amino acid in animal nutrition. Wallingford: CABI Publishing; 2003. p.187203.

Pesti GM, Vedenov D, Cason JA, Billard L. A comparison of methods to estimate nutritional requirements from experimental data. British Poultry Science 2009;50:16-32.

Rostagno HS, Albino LFT, Donzele JL, Gomes PC, Oliveira RFM, Lopes DC, Ferreira AS, Barreto SLT. Tabelas brasileiras para aves e suínos: composição de alimentos e exigências nutricionais. 2nd ed. Viçosa (MG); 2005

Sakomura NK, Rostagno HS. Métodos de pesquisa em nutrição de monogástricos. Jaboticabal: Funep; 2007

Siqueira JC, Sakomura NK, Rostagno HS, Bonato MA, Pinheiro SRF Nascimento DCN. Exigência de lisina para mantença determinada com galos de diferentes genótipos. Revista Brasileira de Zootecnia 2011;40:812-820

Sklan D, Noy Y. Catabolism and deposition of amino acids in growing chicks: effect of dietary supply. Poultry Science 2004;83:952-961.

Statistical Analysis System Institute. SAS user's guide: statistics. $5^{\text {th }}$ ed. Cary: SAS Institute; 2002. 